\title{
Optimization strategy of operation and maintenance based on econometric model
}

\author{
Xuefei Zhang ${ }^{1}$, Zhiwei $\mathrm{Li}^{1}$, Chengzhi Wang ${ }^{2}$, Xuejun Tang ${ }^{1}$,Sen Yang ${ }^{3 *}$ \\ ${ }^{1}$ State Grid Hubei Economic Research Institute, Technology and Economic Center, Wuhan, Hubei \\ ${ }^{2}$ State Grid Hubei Electric Power Co., Ltd. Wuhan, Hubei \\ ${ }^{3}$ Central China Technology Development Co,Ltd. Wuhan, Hubei
}

\begin{abstract}
With the continuous development of power grid, the investment of equipment assets is increasing sharply during the 13th Five Year Plan Period. There is a growing need for equipment maintenance as the equipment ages and varies in different types from transmission to distribution equipment. Equipment is the base element of healthy power grid development. Therefore, it is important to raise the efficiency and quality of equipment status via operation and maintenance. To improve the effectiveness of equipment maintenance, reduce the maintenance cost, improve the safe operation level and power supply reliability of power grid, this paper uses econometric model of correlation analysis to build the correlation between daily overhaul, operation and maintenance and fault frequency and voltage qualification rate, so as to provide optimal decision for the development of operation, inspection and maintenance of power grid company.
\end{abstract}

\section{Introduction}

With the continuous advancement of the development process of the power grid, the investment in equipment assets is increasing, and the large number of transmission and distribution equipment has led to the continuous increase of equipment maintenance workload. Therefore, it is necessary to formulate an optimized maintenance strategy to effectively reduce the equipment failure rate, reduce maintenance costs, and improve the safe operation of the power grid. The current research on power grid operation and maintenance strategy is divided into the following aspects: equipment health evaluation, equipment risk analysis and evaluation, and equipment reliability evaluation.

The equipment health status assessment evaluates the status of the equipment during the operation stage and makes decisions for optimization of operation inspection and maintenance based on the equipment in-operation status score. Sun Caixin uses a centralized distributed online monitoring and diagnosis system to evaluate and predict the health status and remaining life of power transmission and transformation equipment; Xie Hongling, Lu Fangcheng use information fusion technology to predict the operating status of a single type of transformer equipment evaluation. Subsequently, information fusion technology is widely used in the state assessment of power grid equipment. Fu Haochuan proposed a transformer fault diagnosis and condition assessment technology based on DSMT information fusion. Zheng Ruirui and Zhao Jiyin used the weighted gray target theory to evaluate the insulation state of power transformers. Equipment risk analysis and assessment is the result of quantifying the degree of equipment risk. Equipment risk analysis and assessment methods include qualitative, semi-quantitative and quantitative risk assessment methods. Equipment reliability evaluation is based on the analysis of related reliability indicators based on the operating data of the equipment, or through the equipment's own function, failure mode and failure impact analysis. The main methods include Markov model and fault tree analysis method.

The above research provides the basic theory for the research of this article. The equipment maintenance arrangement should not only consider the electrical coupling relationship of the equipment in space, but also the loss results caused by the equipment maintenance on the power system at different operation modes and different moments. Therefore, equipment maintenance is a complicated decision-making process. It is difficult to optimize the scheduling of maintenance plans based on the reliability, risk assessment, and health assessment of the power grid and equipment, which is difficult to meet the actual application requirements.

\section{Vector autoregressive model}

The vector autoregressive model can analyze the dynamic interaction between different variables in economic phenomena and construct the model by taking each endogenous variable in the system as a function of the lag value of all endogenous variables in the system, effectively solving the data limitations of shorter length and greater individual heterogeneity. Before the

*Corresponding author:13120686308@163.com 
establishment of the vector autoregressive model, it is necessary to establish a first-order lag model based on the minimum value of AIC, BIC and HQIC based on ensuring the stability of the data: the VAR model describes that $n$ variables (endogenous variables) within the same sample period can be used as linear functions of their past values.

The VAR(p) model can be written as:

$$
Y t=c+A 1(y t-1)+A 2(y t-2)+\ldots .+A p(y t-p)+e t
$$

In this notation: $\mathrm{c}$ is an $\mathrm{n} \times 1$ constant vector, $\mathrm{Ai}$ is an $\mathrm{n} \times \mathrm{n}$ matrix. et is an $\mathrm{n} \times 1$ error vector, which satisfies:

(1) The mean value of the error term is 0 ;

(2) The covariance matrix of the error term is $\Omega(n \times n$ positive definite matrix);

(3) (Satisfied for all $\mathrm{k}$ that is not 0)-There is no autocorrelation in the error term.

Table1. Relevant data of the company from 2016 to 2019

\begin{tabular}{|c|c|c|c|c|c|c|c|c|}
\hline year & month & $\begin{array}{l}\text { urban } \\
\text { power } \\
\text { grid } \\
\text { voltage } \\
\text { qualific } \\
\text { ation } \\
\text { rate } \\
(\%)\end{array}$ & $\begin{array}{c}\text { rural power } \\
\text { grid voltage } \\
\text { qualificatio } \\
\text { n rate } \\
(\%)\end{array}$ & $\begin{array}{c}\text { total } \\
\text { number } \\
\text { of } \\
\text { failures }\end{array}$ & $\begin{array}{l}\text { manageme } \\
\text { nt or } \\
\text { equipment } \\
\text { failure }\end{array}$ & $\begin{array}{l}\text { force } \\
\text { majeure } \\
\text { failure }\end{array}$ & $\begin{array}{c}\text { daily } \\
\text { maintenance } \\
\text { (yuan) }\end{array}$ & $\begin{array}{c}\text { production } \\
\text { overhaul } \\
\text { (yuan) }\end{array}$ \\
\hline \multirow{8}{*}{2016} & May & 99.99 & 99.62 & 0 & 0 & 0 & 33471243 & 69127671 \\
\hline & June & 99.99 & 99.69 & 5 & 1 & 4 & 20131674 & 8593035 \\
\hline & July & 99.99 & 99.61 & 5 & 2 & 3 & 3803262 & 0 \\
\hline & August & 99.99 & 99.46 & 5 & 2 & 3 & 2677404 & 0 \\
\hline & September & 99.99 & 99.71 & 6 & 1 & 5 & 16206812 & 151270 \\
\hline & October & 99.99 & 99.65 & 3 & 1 & 2 & 71702234 & 30738419 \\
\hline & November & 99.99 & 99.91 & 3 & 1 & 2 & 244617304 & 189219492 \\
\hline & December & 100.00 & 99.99 & 1 & 1 & 0 & 307825304 & 56282338 \\
\hline \multirow{12}{*}{2017} & January & 99.99 & 99.76 & 0 & 0 & 0 & 3583596 & 35186 \\
\hline & February & 99.99 & 99.81 & 0 & 0 & 0 & 3940962 & 0 \\
\hline & March & 99.99 & 99.81 & 1 & 1 & 0 & 21613662 & 3702675 \\
\hline & April & 99.99 & 99.80 & 5 & 2 & 3 & 6995076 & 29765 \\
\hline & May & 99.99 & 99.82 & 6 & 3 & 3 & 8070490 & 4452363 \\
\hline & June & 99.99 & 99.80 & 9 & 4 & 5 & 15123641 & 40667464 \\
\hline & July & 99.99 & 99.84 & 4 & 3 & 1 & 19434072 & 5135616 \\
\hline & August & 99.99 & 99.85 & 6 & 0 & 6 & 54403469 & 34502010 \\
\hline & September & 99.99 & 99.86 & 4 & 0 & 4 & 49892163 & 147239073 \\
\hline & October & 99.99 & 99.86 & 2 & 2 & 0 & 86299695 & 106038290 \\
\hline & November & 99.99 & 99.89 & 1 & 0 & 1 & 211933246 & 125511965 \\
\hline & December & 99.99 & 99.95 & 0 & 0 & 0 & 328866859 & 115915559 \\
\hline \multirow{12}{*}{2018} & January & 99.99 & 99.88 & 0 & 0 & 0 & 810156936 & 583229970 \\
\hline & February & 99.99 & 99.87 & 0 & 0 & 0 & 3226446 & 0 \\
\hline & March & 99.99 & 99.88 & 1 & 1 & 0 & 3695169 & 365 \\
\hline & April & 99.99 & 99.88 & 2 & 0 & 2 & 8111722 & 0 \\
\hline & May & 99.99 & 99.89 & 1 & 1 & 0 & 4361439 & 0 \\
\hline & June & 99.99 & 99.90 & 6 & 1 & 5 & 7028240 & 66398747 \\
\hline & July & 99.99 & 99.90 & 6 & 0 & 6 & 6004501 & 32746678 \\
\hline & August & 99.99 & 99.91 & 5 & 1 & 4 & 32511314 & 5033942 \\
\hline & September & 99.99 & 99.91 & 3 & 1 & 2 & 25446361 & 8038506 \\
\hline & October & 99.99 & 99.92 & 2 & 1 & 1 & 54417503 & 58984436 \\
\hline & November & 99.99 & 99.98 & 0 & 0 & 0 & 66759380 & 28629284 \\
\hline & December & 99.99 & 99.91 & 1 & 1 & 0 & 211900768 & 107301060 \\
\hline 2019 & January & 99.99 & 99.91 & 1 & 0 & 1 & 11755388 & 0 \\
\hline
\end{tabular}

\section{Case analysis}

Based on the results of the equipment status data, taking full consideration of the development of the power grid and technological progress, the company counts the number of failures from 2016 to 2019, studies the specific factors that affect the number of failures, and analyzes the number of business and failures such as overhaul and maintenance. The relationship between index changes, and thus determine the maintenance method in combination with technical standards and provide data support for optimizing the operation and maintenance strategy.

\subsection{Initial data}

The original data is shown in Table 1: 


\begin{tabular}{|c|c|c|c|c|c|c|c|c|}
\hline \multirow{7}{*}{} & February & 99.99 & 99.93 & 0 & 0 & 0 & 61436233 & 0 \\
\cline { 2 - 8 } & March & 99.99 & 99.92 & 5 & 1 & 4 & 38986052 & 0 \\
\cline { 2 - 8 } & April & 99.99 & 99.92 & 5 & 1 & 4 & 53598625 & 3625088 \\
\cline { 2 - 8 } & May & 99.99 & 99.92 & 11 & 1 & 10 & 186577062 & 152516 \\
\cline { 2 - 9 } & June & 99.99 & 99.93 & 2 & 0 & 2 & 91256019 & 2146256 \\
\cline { 2 - 9 } & July & 99.99 & 99.94 & 7 & 2 & 5 & 101352164 & 24801466 \\
\cline { 2 - 9 } & August & 99.99 & 99.94 & 7 & 2 & 5 & 11534763 & 27451496 \\
\cline { 2 - 9 } & September & 99.99 & 99.94 & 5 & 3 & 2 & 103227168 & 49875153 \\
\cline { 2 - 9 } & October & 99.99 & 99.95 & 0 & 0 & 0 & 150284355 & 104745922 \\
\cline { 2 - 9 } & November & 99.99 & 99.95 & 1 & 0 & 1 & 390301542 & 319295264 \\
\cline { 2 - 8 } & December & 99.99 & 99.95 & 1 & 0 & 1 & 823346058 & 427041280 \\
\hline
\end{tabular}

This article divides the faults into management or equipment faults and force majeure faults. Management or equipment failures include failures that can be avoided through regular maintenance and overhaul such as unqualified parts, equipment aging, and poor workmanship. Force majeure failures include unavoidable failures caused by nature such as strong winds, fires, and animal influences. At the same time, the voltage qualification rate can be divided into two parts: urban power grid and rural power grid. Obviously, the number of failures as a dependent variable has an inverse relationship with the cost of daily maintenance and production overhaul of the enterprise, and the relationship between the voltage qualification rate and the cost cannot be easily seen. The following model uses econometric methods to conduct research. Select the period from May 2016 to May 2019 as the training set, and June to December 2019 as the test set.

\subsection{Data check}

\subsubsection{Stationarity test}

For the 25 sets of data in Table 1 from May 2016 to May 2019, the stationarity ADF test was performed in turn, and the results are shown in Table 2.

Table2. ADF inspection result

\begin{tabular}{|c|c|c|c|c|c|c|}
\hline variable & $\begin{array}{c}\text { difference } \\
\text { order }\end{array}$ & $\begin{array}{c}\text { ADF inspection } \\
\text { value }\end{array}$ & $1 \%$ threshold & $5 \%$ threshold & $10 \%$ threshold & $\begin{array}{c}\text { conclusio } \\
n\end{array}$ \\
\hline $\begin{array}{c}\text { total number of } \\
\text { failures }\end{array}$ & 1 & -2.715088 & -3.639407 & -2.951125 & -2.6143 & stable \\
\hline $\begin{array}{c}\text { management or } \\
\text { equipment failure }\end{array}$ & 1 & -6.349911 & -3.6329 & -2.948404 & -2.612874 & stable \\
\hline force majeure failure & 1 & -7.532175 & -3.6329 & -2.948404 & -2.612874 & stable \\
\hline daily maintenance cost & 1 & -7.879247 & -3.6329 & -2.948404 & -2.612874 & stable \\
\hline $\begin{array}{c}\text { production overhaul } \\
\text { costs }\end{array}$ & 1 & -9.517656 & -3.6329 & -2.948404 & -2.612874 & stable \\
\hline $\begin{array}{c}\text { urban power grid } \\
\text { voltage qualification } \\
\text { rate }\end{array}$ & 1 & -4.929953 & -3.65373 & -2.95711 & -2.617434 & stable \\
\hline $\begin{array}{c}\text { rural power grid } \\
\text { voltage qualification } \\
\text { rate }\end{array}$ & 1 & -8.040796 & -3.6329 & -2.948404 & -2.612874 & stable \\
\hline
\end{tabular}

As is shown in Table 2, under the premise of the firstorder difference, all variables pass the stationarity test (the stationarity test of the total number of failures is based on the significance of $10 \%$ ). Therefore, the cointegration test can be further implemented.
The total number of failures, the number of management or equipment failures, the number of force majeure failures, and the cost are used for co-integration tests. The results are shown in Tables 3, 4, and 5 .

\subsubsection{Cointegration test}

Table3. Cointegration test results of the total number of failures

\begin{tabular}{|c|c|c|c|}
\hline hypothesis & test value & 5\%threshold & P value \\
\hline No cointegration equation & 17.54281 & 21.13162 & 0.1479 \\
\hline At most one cointegration equation & 12.64891 & 14.2646 & 0.0886 \\
\hline At most two cointegration equations & 3.574978 & 3.841466 & $0.0587^{*}$ \\
\hline
\end{tabular}

As is shown in Table 3, the "no cointegration equation" hypothesis of the total number of failures, daily maintenance and production overhaul is rejected, and the hypothesis of "at most one cointegration equation" is also 
rejected, and "at most two cointegration equations" are also rejected. The $\mathrm{P}$ value of 0.0587 is close to $5 \%$, it can be approximately considered that the assumption of "at

Table4. Cointegration test results of management or equipm

\begin{tabular}{|c|c|c|c|}
\hline Typothesis & test value & $5 \%$ threshold & P value \\
\hline No cointegration equation & 15.84484 & 21.13162 & 0.234 \\
\hline At most one cointegration equation & 12.21744 & 14.2646 & 0.1027 \\
\hline At most two cointegration equations & 10.51324 & 3.841466 & 0.0012 \\
\hline
\end{tabular}

As is shown in Table 4, the "no cointegration equation" hypothesis of the number of management or equipment failures, daily maintenance, and production overhaul was rejected, and the hypothesis of "at most one cointegration equation" was rejected, and "at most two cointegration equations" were accepted, which means most two cointegration equations" is accepted. In summary, the total number of failures barely passes the cointegration test.

Table5. Cointegration test results of the number of force majeure failures

\begin{tabular}{|c|c|c|c|}
\hline hypothesis & test value & $5 \%$ threshold & P value \\
\hline No cointegration equation & 17.78221 & 21.13162 & 0.1382 \\
\hline At most one cointegration equation & 12.06126 & 14.2646 & 0.1084 \\
\hline At most two cointegration equations & 3.709849 & 3.841466 & $0.0541^{*}$ \\
\hline
\end{tabular}

As is shown in Table 5, the number of force majeure failures is similar to the total number of failures, which barely passes the cointegration test.

Table6. Cointegration test result of voltage qualification rate (urban power grid)

\begin{tabular}{|c|c|c|c|}
\hline hypothesis & test value & 5\%threshold & P value \\
\hline No cointegration equation & 16.21648 & 21.13162 & 0.2125 \\
\hline At most one cointegration equation & 11.73159 & 14.2646 & 0.1211 \\
\hline At most two cointegration equations & 8.864727 & 3.841466 & 0.0029 \\
\hline
\end{tabular}

As is shown in Table 6, the voltage qualification rate (urban power grid) rejects the assumptions of "no cointegration equation" and "at most one cointegration equation" for daily maintenance and production overhaul and accepts the assumption of "at most two cointegration

Table7. Cointegration test result of there are two cointegration equations for the number of management or equipment failures, daily maintenance, and production overhaul. In summary, the number of management or equipment failures passes the cointegration test.

\begin{tabular}{|c|c|c|c|}
\hline Table7. Cointegration test result of voltage qualification rate (rural power grid) \\
\hline hypothesis & test value & $5 \%$ threshold & P value \\
\hline No cointegration equation & 12.31471 & 21.13162 & 0.5169 \\
\hline At most one cointegration equation & 10.66989 & 14.2646 & 0.1715 \\
\hline At most two cointegration equations & 4.08315 & 3.841466 & 0.0433 \\
\hline
\end{tabular}

As is shown in Table 7, the voltage qualification rate (rural power grid) has passed the cointegration test.

\subsection{VAR model validation}

Based on the above test, since the number of failures and the voltage qualification rate have passed the stationarity test and the cointegration test, there can be sufficient basis to construct a VAR (vector autoregressive) model of the number of failures, voltage qualification rate and cost.

\subsubsection{VAR model based on the number of failures}

\subsubsection{VAR model of the total number of failures}

equations". And the $\mathrm{P}$ value is more obviously close to 0 . Therefore, it can be considered that the voltage qualification rate (urban power grid) has a strong cointegration with daily maintenance and production overhaul.

The daily maintenance cost and the production overhaul cost are selected as independent variables, and the total number of failures is the dependent variable which means selecting 25 sets of data from May 2016 to May 2019 as the training set, and the lag period is six for model building. Finally, the regression equation is as follows:

$y 3=0.233291957311 * y 3(-1)+0.348034116375 * y 3(-2)-$
$0.312947975731 * y 3(-3)-0.118766433885 * y 3(-4)-$
$0.124158543242 * y 3(-5)-0.171263165892 * y 3(-$
$6)+3.77271083653 e-09 * x 1(-1)-2.33663390628 e-$
$10 * x 1(-2)+5.54806740231 e-09 * x 1(-$
$3)+7.25647914648 e-09 * x 1(-4)+5.14399983 e-09 * x 1(-$
$5)+6.69192875897 e-09 * x 1(-6)-4.41744016992 e-$
$09 * x 2(-1)-2.39796777921 e-09 * x 2(-2)-1.01260985664 e-$


$08 * x 2(-3)-1.81545382764 e-08 * x 2(-4)-5.32070655695 e-$ $09 * x 2(-5)-6.32087575147 e-09 * x 2(-6)+3.62507058227$

(2)

y3 - Total number of failures

$\mathrm{x} 1$-Daily maintenance cost

$\mathrm{x} 2 \_$Production overhaul costs
The number in parentheses after the variable is the lag period. For example, $(-1)$ is the data with the lag period of 1 , which will not be repeated hereafter.

The goodness of fit R2 of the VAR model in the formula (2) is 0.816608 , which can be considered as a high reliability of the regression model.

Using the formula, you can calculate the data of the test set from June to December 2019 and compare it with the actual value. The results are shown in Table 8:

Table8. VAR model test results of the total number of failures

\begin{tabular}{|c|c|c|c|}
\hline month & the actual data & calculate data & difference \\
\hline June & 2 & 4.199708 & 2.199708 \\
\hline July & 7 & 4.867157 & 2.132843 \\
\hline August & 7 & 4.758956 & 2.241044 \\
\hline September & 5 & 4.713887 & 0.286113 \\
\hline October & 0 & 3.864053 & 3.864053 \\
\hline November & 1 & 3.362081 & 2.362081 \\
\hline December & 1 & 2.428541 & 1.428541 \\
\hline
\end{tabular}

The test result Figure1 is Drawn through Table 8. At the same time, the mean absolute deviation (MAD), mean square error (MSE) and mean absolute percentage error

(MAPE) of the data test results are calculated, and the results are shown in Table 9:

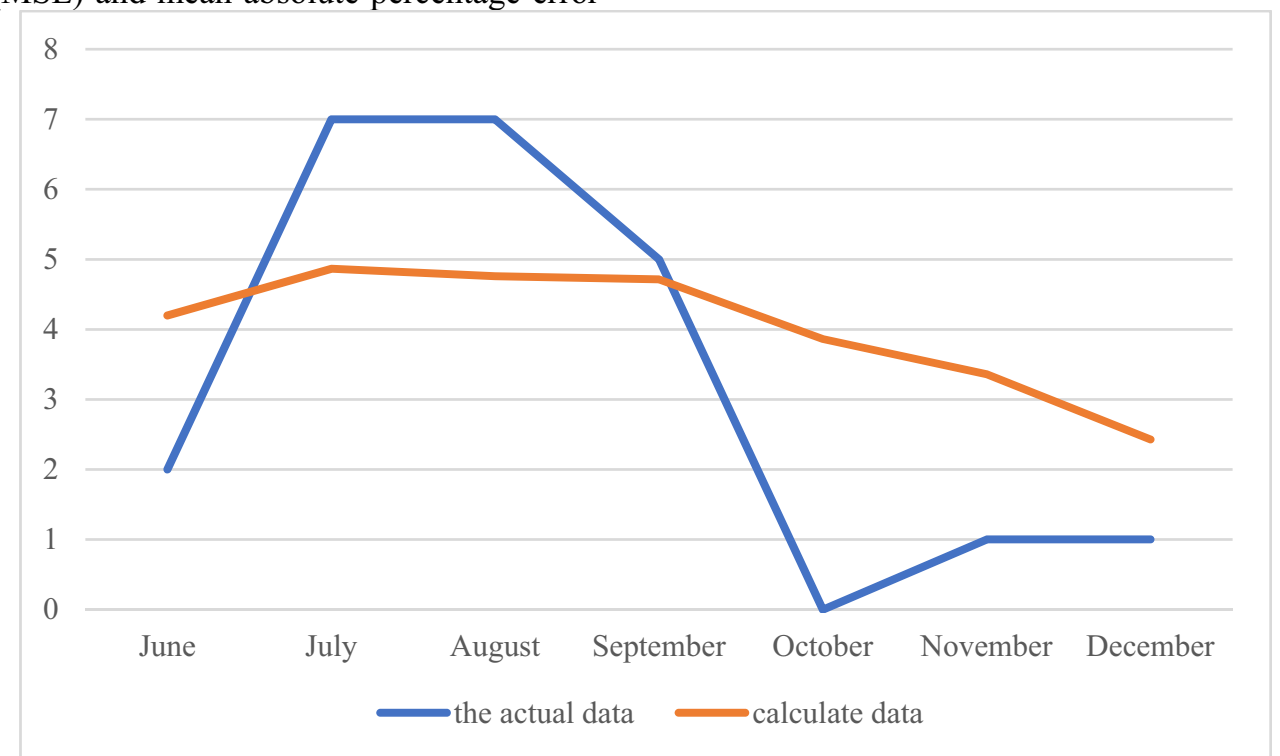

Figure 1. Comparison of VAR model test results of total failure times

Table9. Statistics related to the test results of the total number of failures

\begin{tabular}{|c|c|c|}
\hline MAD & MSE & RMSE \\
\hline 2.073483286 & 5.291847862 & 2.300401674 \\
\hline
\end{tabular}

It can be seen from the above chart that the regression results are not much different from the actual results, and there is reason to believe that the VAR regression model is in line with expectations.

\subsubsection{VAR model of management or equipment failure times}

$y 4=0.322680812357 * y 4(-1)-0.316106928815 * y 4(-$ 2) $+0.300587584217 * y 4(-3)-0.373644034066 * y 4(-4)-$ $0.381809180492 * y 4(-5)+0.176415941427 * y 4(-6)-$ $7.86439707952 e-09 * x 1(-1)+1.40196901522 e-10 * x 1(-$ 2) $+2.01835219983 e-09 * x 1(-3)+6.14259580961 e-$ $09 * x 1(-4)+8.51814444969 e-09 * x 1(-$
$5)+5.10748872549 e-09 * x 1(-6)+1.35614490293 e-$ $08 * x 2(-1)+3.44785585389 e-09 * x 2(-2)-$

$6.73964375168 e-09 * x 2(-3)-1.00562274526 e-08 * x 2(-4)-$ $1.42129708726 e-08 * x 2(-5)-9.66649320875 e-09 * x 2(-$ 6) +1.32458487222

y4-Management or equipment failure times

$\mathrm{x} 1$-Daily maintenance cost

$\mathrm{x} 2$-Production overhaul costs

The goodness of fit R2 of the VAR model in the formula is 0.715973 , and the regression model can be highly reliable.

Similarly: 
Table10. VAR model test results of management or equipment failure times

\begin{tabular}{|c|c|c|c|}
\hline month & the actual data & calculate data & difference \\
\hline June & 0 & 1.101109 & 1.101109 \\
\hline July & 2 & 1.12482 & 0.87518 \\
\hline August & 2 & 1.14109 & 0.85891 \\
\hline September & 3 & 1.141664 & 1.858336 \\
\hline October & 0 & 1.120898 & 1.120898 \\
\hline November & 0 & 1.099916 & 1.099916 \\
\hline December & 0 & 1.046206 & 1.046206 \\
\hline
\end{tabular}

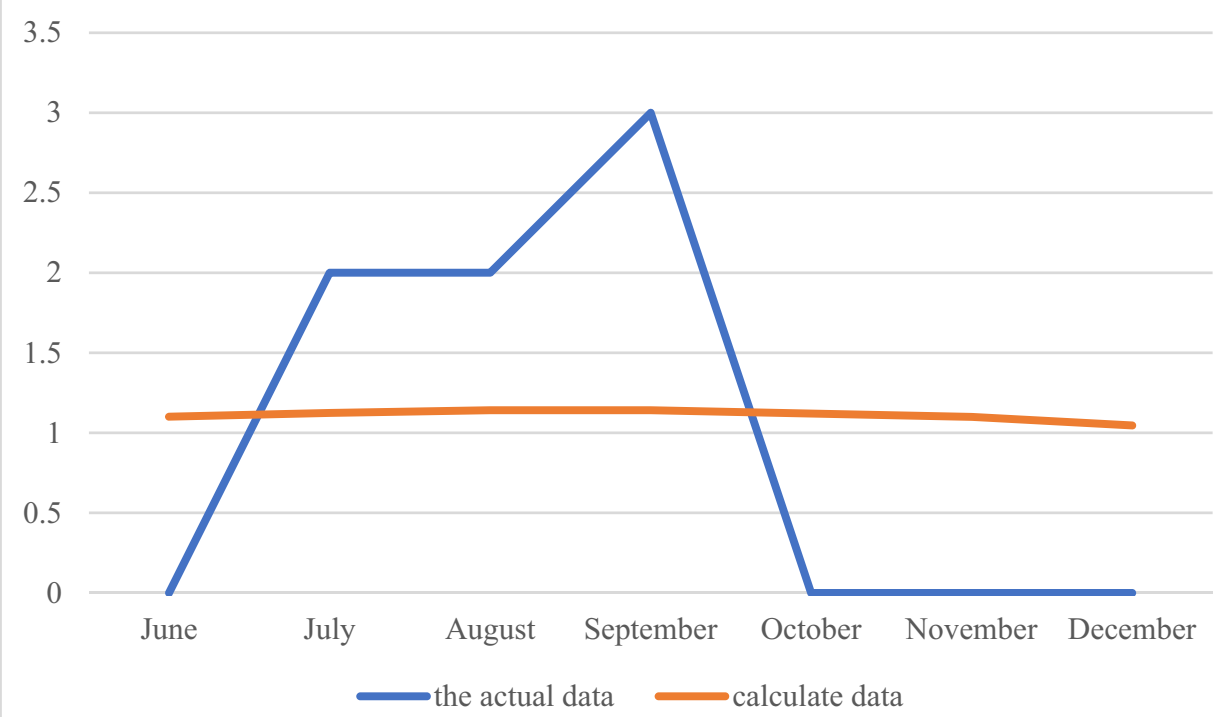

Figure 2. Comparison of VAR model test results of management or equipment failure times Table11. Statistical values related to test results of management or equipment failure times

\begin{tabular}{|c|c|c|}
\hline MAD & MSE & RMSE \\
\hline 1.137222143 & 1.390042095 & 1.179000465 \\
\hline
\end{tabular}

It can be seen from the above chart that the regression results are not much different from the actual results, and there is reason to believe that the VAR regression model is in line with expectations.

\subsubsection{VAR model of the number of force majeure failures}

$y 5=0.087792909722 * y 5(-1)+0.14347219482 * y 5(-2)-$

$0.182179963835 * y 5(-3)-0.1426772053 * y 5(-4)-$

$0.366774281746 * y 5(-5)-0.370451863619 * y 5(-$

$6)+7.70988340879 e-09 * x 1(-1)-3.28663676809 e-$

$10 * x 1(-2)+3.75251805344 e-09 * x 1(-$

$3)+2.60671250707 e-09 * x 1(-4)-1.17773856496 e-$
$09 * x 1(-5)-4.80924087974 e-10 * x 1(-6)-9.17941343405 e-$ $09 * x 2(-1)-4.62919405829 e-09 * x 2(-2)-7.46101063097 e-$ $09 * x 2(-3)-1.14653176494 e-08 * x 2(-$

$4)+3.25723691674 e-09 * x 2(-5)+4.36850430365 e-$ $09 * x 2(-6)+4.04478345279$

y5-Number of force majeure failures

$\mathrm{x} 1$-Daily maintenance cost

$\mathrm{x} 2$ _ Production overhaul costs

The goodness of fit R2 of the VAR model in the formula is 0.418338 , and it can be considered that the reliability of the regression model is not high.

Similarly:

Table12. VAR model test results of the number of force majeure failures

\begin{tabular}{|c|c|c|c|}
\hline month & the actual data & calculate data & difference \\
\hline June & 2 & 3.960657 & 1.960657 \\
\hline July & 5 & 3.851676 & 1.148324 \\
\hline August & 5 & 2.951655 & 2.048345 \\
\hline September & 2 & 2.123014 & 0.123014 \\
\hline October & 0 & 1.134799 & 1.134799 \\
\hline November & 1 & 0.7002217 & 0.2997783 \\
\hline December & 1 & 0.716134 & 0.283866 \\
\hline
\end{tabular}




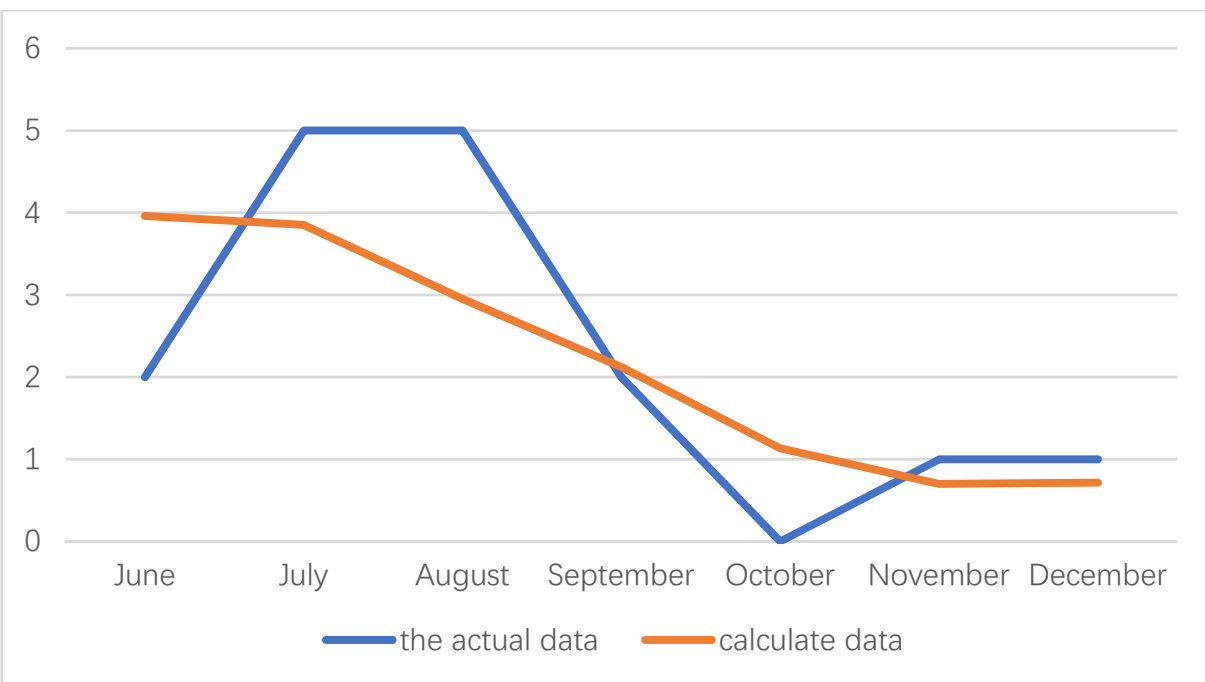

Figure 3. Comparison of VAR model test results of the number of force majeure failures

Table13. Statistics related to the number of force majeure failures test results

\begin{tabular}{|c|c|c|}
\hline MAD & MSE & RMSE \\
\hline 0.999826186 & 1.547412753 & 1.243950462 \\
\hline
\end{tabular}

It can be seen from the above chart that the regression results are not much different from the actual results, and there is reason to believe that the VAR regression model is in line with expectations.

\subsubsection{VAR model based on voltage qualification rate}

\subsubsection{Urban power grid VAR model}

$y 1=-0.111454113664 * y 1(-1)-0.315704764164 * y 1(-2)-$ $0.186504708187 * y 1(-3)+0.024111316159 * y 1(-$ 4) $+0.124747734257 * y 1(-5)-0.200064259248 * y 1(-6)-$ $6.6856632735 e-12 * x 1(-1)-9.58152689052 e-14 * x 1(-2)-$ $8.45369416385 e-13 * x 1(-3)-4.02959638438 e-12 * x 1(-$

4) $+6.53044648717 e-13 * x 1(-5)-3.20354297012 e-$ $12 * x 1(-6)+8.81510778901 e-12 * x 2(-1)-$ $3.09267346424 e-13 * x 2(-2)+1.48050747426 e-12 * x 2(-$ $3)+5.8059944958 e-12 * x 2(-4)+2.58237987646 e-$ $12 * x 2(-5)-6.24578287968 e-13 * x 2(-6)+166.48379447$

y1—Voltage qualification rate (urban power grid)

$\mathrm{x} 1$-Daily maintenance cost

$\mathrm{x} 2$ _Production overhaul costs

The goodness of fit R2 of the VAR model in the formula is 0.593508 , which means that the reliability of the regression model is general.

Similarly:

\begin{tabular}{|c|c|c|c|}
\hline month & the actual data & calculate data & difference \\
\hline June & 99.999 & 99.99793 & 0.00107 \\
\hline July & 99.996 & 99.99808 & 0.00208 \\
\hline August & 99.999 & 99.99783 & 0.00117 \\
\hline September & 99.999 & 99.99799 & 0.00101 \\
\hline October & 99.999 & 99.99797 & 0.00103 \\
\hline November & 99.999 & 99.99792 & 0.00108 \\
\hline December & 99.996 & 99.99802 & 0.00202 \\
\hline
\end{tabular}




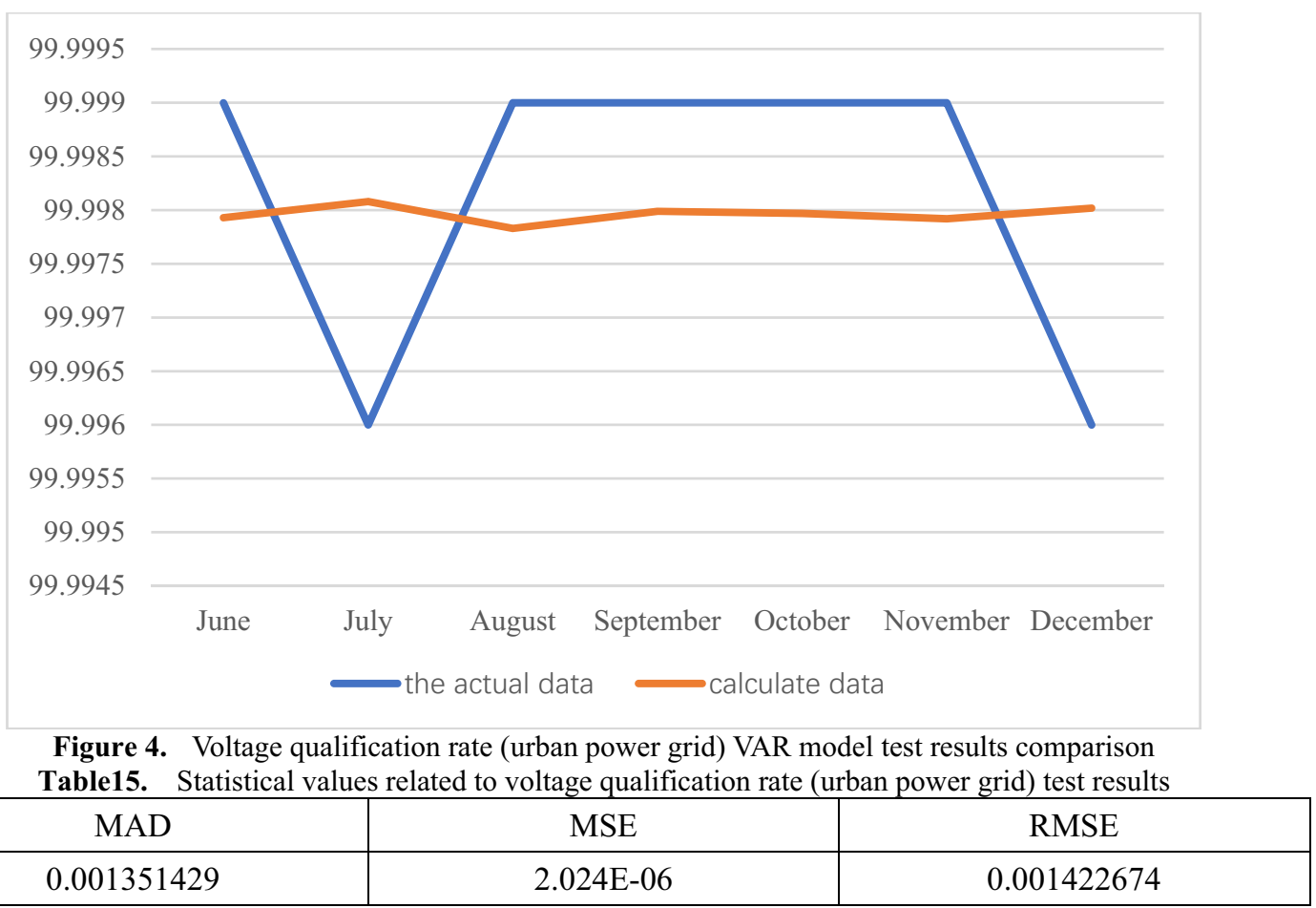

It can be seen from the above chart that the regression results are not much different from the actual results, and there is reason to believe that the VAR regression model is in line with expectations.

\subsubsection{Rural power grid VAR model}

$y 2=0.0847433733371 * y 2(-1)-0.137846730185 * y 2(-$

2) $+0.216414845175 * y 2(-3)-0.469208555783 * y 2(-$

$4)+0.152184242946 * y 2(-5)+0.267154268158 * y 2(-$

6) $+6.30753711095 e-11 * x 1(-1)-8.88330419569 e-11 * x 1(-$

2) $-2.05024249578 e-10 * x 1(-3)-4.31708216383 e-11 * x 1(-$

4) $-6.77630428006 e-10 * x 1(-5)-5.1142548533 e-10 * x 1(-$
6) $-2.56612532799 e-10 * x 2(-1)-1.26202014108 e-10 * x 2(-$ 2) $+2.49823385654 e-10 * x 2(-3)+2.06211305983 e-$ $10 * x 2(-4)+1.03770044411 e-09 * x 2(-$

$5)+7.10245137294 e-10 * x 2(-6)+88.5880858156$
y2_-Voltage qualification rate (rural power grid)

$\mathrm{x} 1$-Daily maintenance cost

$\mathrm{x} 2$ _-Production overhaul costs

The goodness of fit R2 of the VAR model in the formula is 0.774181 , and the regression model can be highly reliable.

Similarly:

Table16. Voltage qualification rate (rural power grid) VAR model test results

\begin{tabular}{|c|c|c|c|}
\hline month & the actual data & calculate data & difference \\
\hline June & 99.936 & 99.86318 & 0.07282 \\
\hline July & 99.942 & 99.86079 & 0.08121 \\
\hline August & 99.944 & 99.85914 & 0.08486 \\
\hline September & 99.943 & 99.85787 & 0.08513 \\
\hline October & 99.951 & 99.8561 & 0.0949 \\
\hline November & 99.952 & 99.85382 & 0.09818 \\
\hline December & 99.953 & 99.85216 & 0.10084 \\
\hline
\end{tabular}




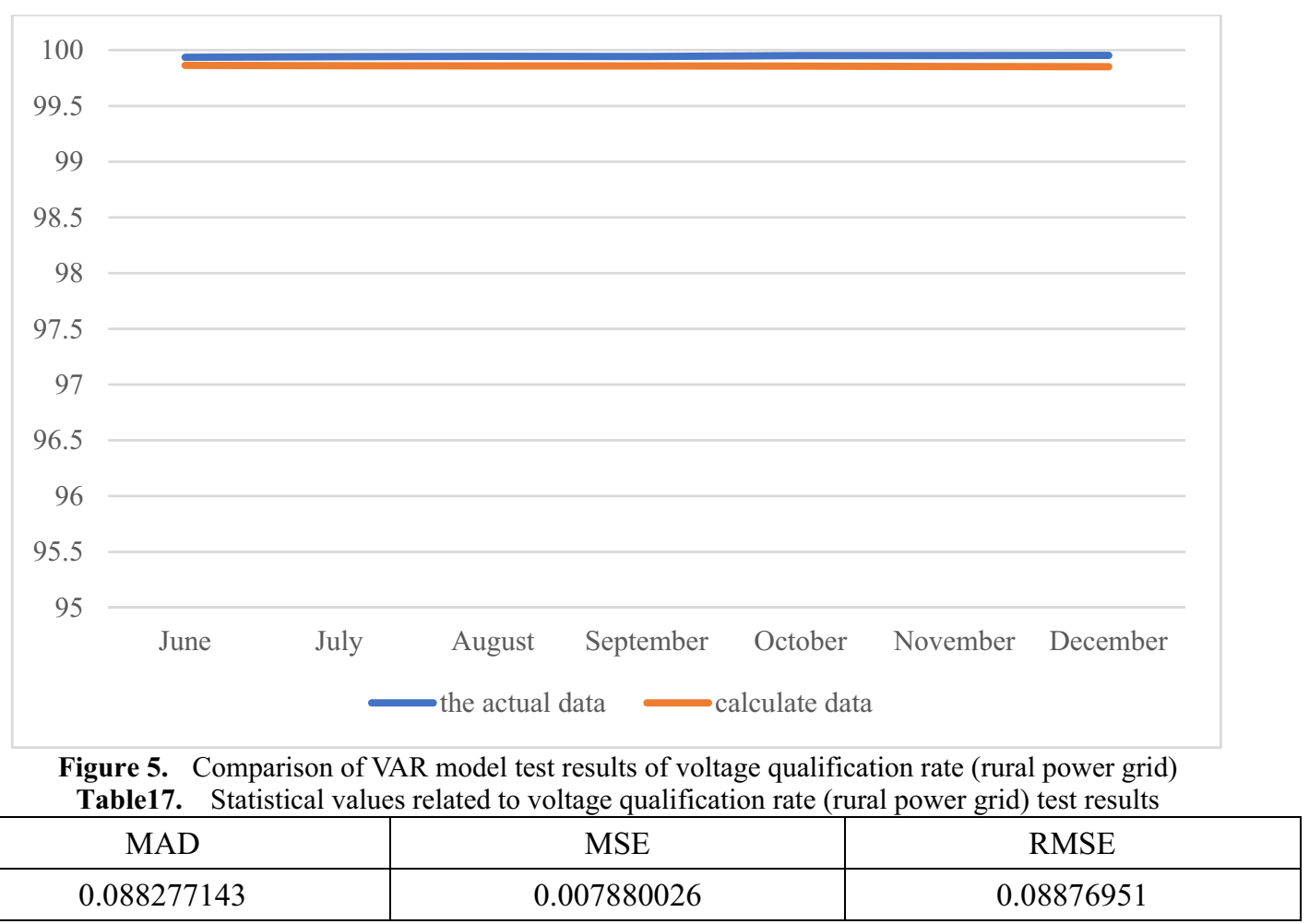

It can be seen from the above chart that the regression results are not much different from the actual results, and there is reason to believe that the VAR regression model is in line with expectations.

By constructing a VAR model of the number of failures and costs, the regression analysis of the business and the number of failures indicators such as overhaul and maintenance has been carried out, and the following conclusions have been drawn:

(1) Although the simulation superiority of VAR model for total number of failures is very high, the coefficient of daily maintenance cost is mostly positive. Considering that the total number of failures is composed of management or equipment failures and force majeure failures, the credibility of VAR model for total number of failures is not high, so VAR model for each failure should be analyzed in detail.

(2) There is a high degree of correlation between the number of management or equipment failures, daily maintenance costs, and production overhaul costs. On the one hand, the reason is that the VAR model has a high degree of simulation; on the other hand, the difference between the regression results and the actual results is small.

(3) There is basically no correlation between the number of force majeure failures, daily maintenance costs, and production overhaul costs. The reason is mainly because the simulation goodness of the VAR model is lower than 0.5 , which is not credible.

(4) The voltage qualification rate (urban power grid) is not highly correlated with the cost of daily maintenance and production overhaul, because its goodness of fit is only 0.593508 . This also reflects that the company's urban power grid development has basically matured in recent years and is no longer significantly affected by factors such as equipment operation, maintenance, and repair strategies.

(5) The voltage qualification rate (rural power grid) is highly correlated with daily maintenance costs and production and overhaul costs. It not only reflects its goodness of fit of 0.774181 , but also has a larger coefficient comparison between daily maintenance costs and production and overhaul costs (urban power grids). And from the positive and negative point of view of the coefficient, it can be found that the positive coefficient of daily maintenance is before the cost of 1 in the lag period, and the positive coefficient of production overhaul is before the cost of 3, 4, 5, and 6 in the lag period.

(6) From the perspective of VAR models with high reliability, the coefficient of production overhaul is smaller than the coefficient of daily maintenance.

\section{Conclusion}

(1) Considering the influence of seasons and terrain characteristics on equipment failures, it is necessary to strengthen the operation, maintenance and troubleshooting of equipment before the coming of summer and establish a complete disaster prevention and mitigation plan to ensure the normal operation of the equipment as far as possible. In case of force majeure which can also respond at the fastest speed, reduce the duration of power outages, and ensure the reliability of power supply.

(2) The company actively responded to the policy and paid full attention to the development of rural power grids. The voltage qualification rate of rural power grids has been increasing year by year. In the future, the construction of rural power grid can still be improved by 
increasing the cost of daily maintenance and operation and maintenance.

(3) The investment in daily maintenance costs and production overhaul costs can effectively reduce the total number of failures and increase the voltage qualification rate, which is embodied in the number of management or equipment failures and rural power grids. However, there were no significant results in the number of force majeure failures and the urban power grid.

(4) In terms of fault times and voltage qualification rate, the lag time of production overhaul cost is longer than that of daily maintenance cost. In other words, the daily maintenance cost can quickly work in these two aspects, while the production overhaul cost can only work after a certain period.

(5) With the same amount of cost input, the impact of production overhaul costs is better than that of daily maintenance costs.

\section{Acknowledgements}

Fund Project: Supported by the Science and Technology Project of State Grid Corporation of China (Contract No.: 5400-202056131A-0-0-00)

\section{References}

1. C. Sun. The status and prospects of on-line monitoring and diagnosis technology of power transmission and transformation equipment $[\mathrm{J}]$. China Electric Power, 38(2), 1-7 (2005)

2. H. Xie, F. Lv. Research on Transformer Condition Evaluation Method Based on Information Fusion[J]. Journal of North China Electric Power University (Natural Science Edition), 2, 8-11 (2006)

3. Y. Deng. Research on Transformer State Evaluation and Fault Diagnosis Method Based on Multidimensional Information Fusion[D]. South China University of Technology (2018)

4. H. Fu. Research on Transformer Fault Diagnosis and Condition Assessment Technology Based on DSMT Information Fusion[D]. North China Electric Power University (2019)

5. R. Zheng, J. Zhao, B. Wu, et al. Grading evaluation method of power transformer insulation state based on weighted gray target theory[J]. Transactions of China Electrotechnical Society, 23(8), 60-66 (2008)

6. J. Ji. Research on key technologies of auxiliary decision support system for condition maintenance of power transmission and transformation equipment based on risk analysis[D]. Huazhong University of Science and Technology (2016)

7. B. Lv, H. Niu. Reliability Modeling and Simulation of Signalized Intersections[J]. Journal of Transportation Systems Engineering and Information Technology, 11(6), 12-18 (2011)
8. R. Liao, Z. Xiao, J. Gong, et al. Using Markov Model to Evaluate the Reliability of Power Transformers[J]. High Voltage Technology, 36(2), 322-328 (2010)

9. G. Yang, J. Wang, S. Yang. Application of Fault Tree Analysis Method in the Research of Large Power Transformer Faults[J]. Power System Technology, Z2, 367-371 (2006)

10. Y. Wang. Research on Power Transformer Condition Maintenance Decision Method Based on Reliability and Risk Assessment[D]. Chongqing University (2008) 